\title{
Effect of different classes of antihypertensive drugs on central and peripheral pressure in a young patient with hypertension clinical case
}

\author{
Marta Soltysiak, Krystyna Widecka \\ Department of Hypertensiology and Internal Medicine, Pomeranian Medical University in Szczecin
}

\section{Summary}

In recent years, it has been shown that the central pressure correlated with cardiovascular risk and, better than peripheral pressure, provides the risk of serious cardiovascular events. It is known that blood pressure and pulse wave shape are different in different sections of the arterial tree. This difference is related to the age sex, incidence of heart disease, concomitant cardiovascular disease, diabetes, renal failure, used drugs. In young people, with flexible walls of the vessels, the difference between the circumferential pressure, measured at the upper limb and the central pressure can range from a few to over twenty $\mathrm{mmHg}$. In this context, we present a case of a young patient with hypertension treated with antihypertensive fixed dose combination drug.

key words: hypertension, central pressure

Arterial Hypertension 2015, vol. 19, no 1, pages: 50-52 DOI: $10.5603 / A H .2015 .0009$

23-year-old patient with arterial hypertension diagnosed a year ago was admitted to the Hypertension Department for the purpose of diagnostic tests for secondary causes of hypertension. The patient complained of unstable blood pressure, periodic increases in BP to $160 / 100 \mathrm{mmHg}$, despite regular treatment with metoprolol $50 \mathrm{mg}$ daily. 6 weeks before the scheduled diagnostics, patient set oral hormonal contraceptive preparations. The examination revealed overweight, pale skin, stretch marks on thighs, mid-systolic click in mitral valve auscultation area, and high blood pressure.

There was no significant deviations in the laboratory tests (serum: sodium: $141 \mathrm{mmol} / \mathrm{l}$ [N: 135-145], potassium $4.90 \mathrm{mmol} / \mathrm{l}[\mathrm{N}: 3.50-5.50]$; sodium and potassium in the urine collection: sodium $168.30 \mathrm{mmol} /$ $124 \mathrm{~h}$ [N: $40.00-220.00]$, potassium $55.73 \mathrm{mmol} / 24 \mathrm{~h}$
[N: 25.00-125.00]; microalbuminuria: $8.10 \mathrm{mg} /$ day $[\mathrm{N}:<30.00 \mathrm{mg} / 24 \mathrm{~h}] ;$ ACR $3.48 \mathrm{mg} / \mathrm{g}$; plasma renin activity: $3.37 \mathrm{ng} / \mathrm{ml} / \mathrm{h}$ [N: $0.51-2.64]$; plasma renin activity after administration of $2000 \mathrm{ml}$ of $0.9 \% \mathrm{NaCl}: 1.09 \mathrm{ng} / \mathrm{ml} / \mathrm{h}$ [N: $0.26-1.32]$; aldosterone - basic conditions: $102.00 \mathrm{pg} / \mathrm{ml}$ [N: 10-160]; aldosterone after administration of $2000 \mathrm{ml}$ of $0.9 \% \mathrm{NaCl}: 35.00 \mathrm{pg} / \mathrm{ml}$ [N: 6-75]; metanephrine urine collection: $18 \mathrm{~g} / 24 \mathrm{~h}[\mathrm{~N}: 350]$ ). The test results did not reveal potential causes of secondary of hypertension. Only echocardiography revealed flabby anterior leaflet of mitral valve. Angio-CT of the abdomen revealed a small, $2 \mathrm{~mm}$ lodgement in the right renal upper calyx (Figure 1). The average Ambulatory Blood Pressure Monitoring (ABPM) blood pressure values were: 141/ $185 \mathrm{mmHg}$, up to $184 / 113 \mathrm{mmHg}$ (Figure 2). The

Address for correspondence: Marta Soltysiak, MD

Department of Hypertensiology and Internal Medicine

Pomeranian Medical University in Szczecin, Unii Lubelskiej 1, 71-252 Szczecin

tel: (091) 42-53-550, fax: (091) 42-53-552, e-mail: marta.soltysiak00@gmail.com

V M Copyright $@ 2015$ Via Medica, ISSN 2449-6170 


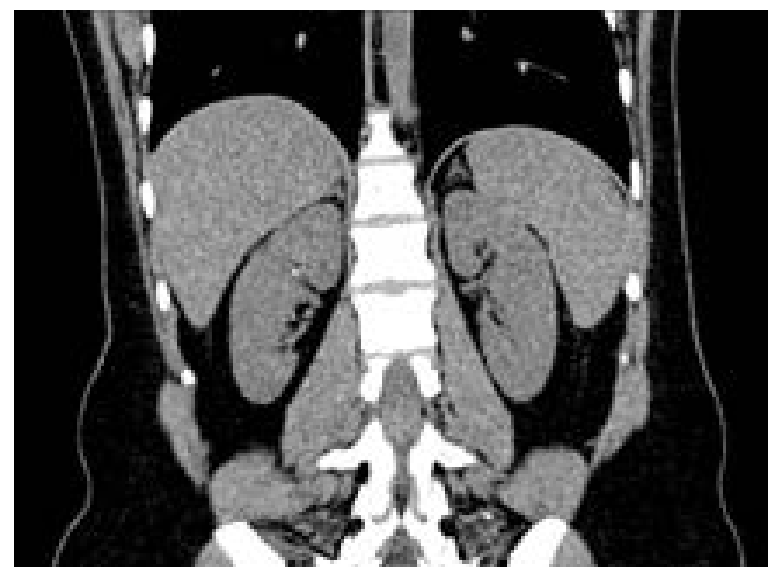

Figure 1. Angio-CT of the abdomen revealed a small, $2 \mathrm{~mm}$, lodgement in right renal upper calyx (Source: Department of Diagnostic Imaging and Interventional Radiology, Pomeranian Medical University, Szczecin, 2014. Courtesy of Prof. Walecka) patient was discharged home with the instruction to take antihypertensive therapy - combined preparation of bisoprolol and amlodipine in daily doses of 5 and $5 \mathrm{mg}$. Follow-up ABPM, taken after 2 months, showed marked improvement (Figure 3). Importantly, pulse wave analysis conducted using the applanation tonometry method showed normalization of central pressure, compared with baseline examination (Figure 4).

In recent years, it has been shown that the central pressure correlated with cardiovascular risk and, better than peripheral pressure, predicts the risk of serious cardiovascular events [1-6]. It is known that blood pressure and pulse wave shape are different in different sections of the arterial tree. This difference is related to the age, sex, incidence of heart disease, concomitant cardiovascular disease, diabetes, renal

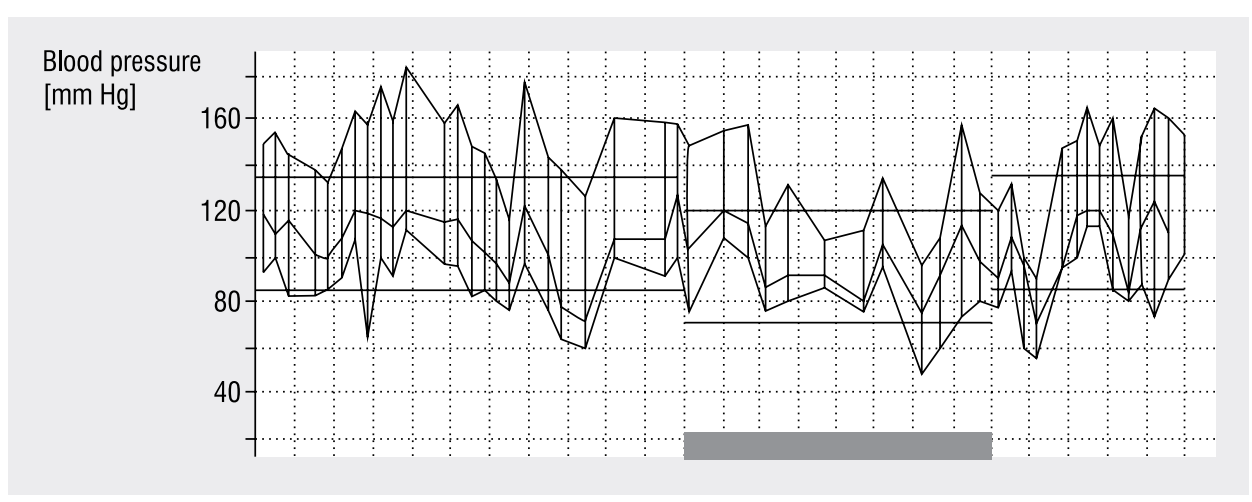

Figure 2. ABPM before modifying treatment: metoprolol $50 \mathrm{mg} /$ day (Source: Department of Hypertensiology and Internal Medicine, Pomeranian Medical University, 2014)

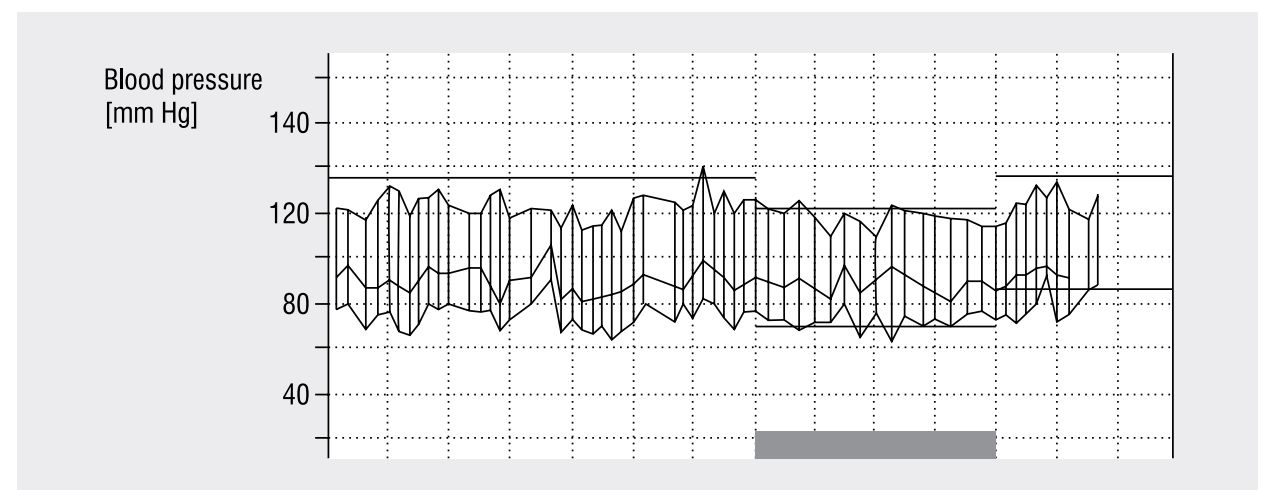

Figure 3. ABPM after modification of treatment: bisoprolol/amlopdypine $5 / 5 \mathrm{mg} /$ day (Source: Department of Hypertensiology and Internal Medicine, Pomeranian Medical University, 2014)

failure, and used drugs $[1,7]$. In young people, with flexible walls of the vessels, the difference between the peripheral pressure, measured at the upper limb, and the central pressure can range from a few to over twenty $\mathrm{mmHg}[1,8]$. The result achieved in our patient seems to be consistent with current scientific reports, which clearly confirms the differences in effect on central pressure of different groups 


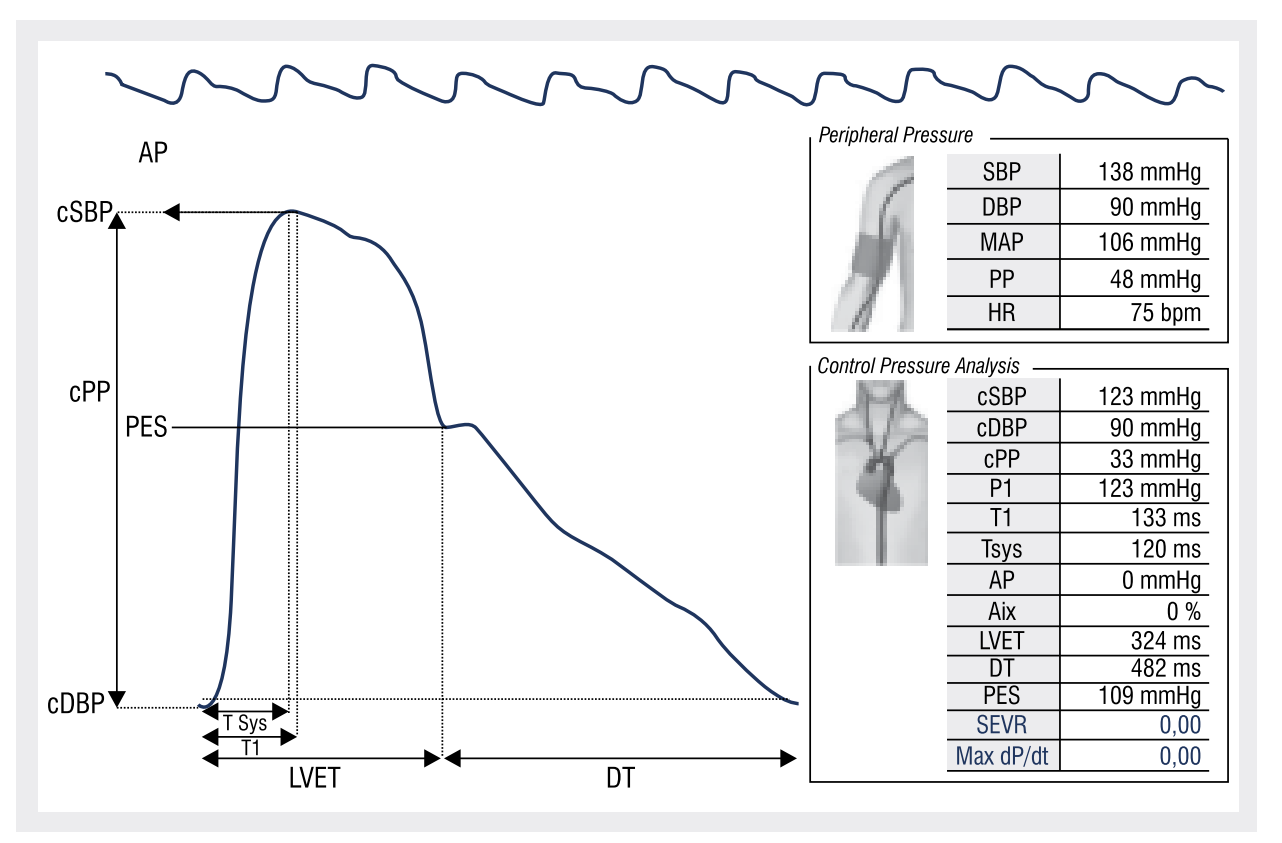

Figure 4. The central pressure curve (Source: Department of Hypertensiology and Internal Medicine, 2014)

of antihypertensive drugs. In this context, have a beneficial effect of angiotensin-converting enzyme inhibitors (ACEI), beta-blockers and amlodipine [9-11]. The first mechanism leading to differences is possible different effects of different drug classes on the speed of the pulse wave velocity (PWV) (best documented is beneficial effect of ACEI on PWV). The second mechanism is the ability to change the pressure wave reflection site distance under the influence of drugs used. Vasodilators such as angiotensin converting enzyme inhibitors, angiotensin receptor blockers or calcium channel blockers move away wave reflection points, while vasoconstrictor drugs and most of the beta-blockers and diuretics - bring them closer. A third potential mechanism is the extended duration of the contraction of the left ventricle as a result of the negative chronotropic action of some drugs (beta-blockers and calcium channel blockers) [14].

\section{References}

1. Jankowski P., Dębicka-Dąbrowska D., Kawecka-Jaszcz K. Wpływ leków przeciwnadciśnieniowych na obwodowe i centralne ciśnienie tętnicze - co lekarz praktyk wiedzieć powinien? Choroby Serca i Naczyń 2008; 5: 209-214.

2. Jankowski P., Kawecka-Jaszcz K., Czarnecka D. et al. Ascending aortic, but not brachial blood pressure-derived indices are related to coronary atherosclerosis. Atherosclerosis 2004; 176: 151-155.

3. Safar M.E., Blacher J., Pannier B. et al. Central pulse pressure and mortality in end-stage renal disease. Hypertension 2002; 39: 735-738.
4. Roman M.J., Devereux R.B., Kizer J.R. et al. Central pressure more strongly relates to vascular disease and outcome than does brachial pressure: the Strong Heart Study. Hypertension 2007; 50: 197-203.

5. Jankowski P., Kawecka-Jaszcz K., Czarnecka D. et al. Pulsatile but not steady component of blood pressure predicts cardiovascular events in coronary patients. Hypertension 2008; 51: 848-855.

6. Pini R., Cavallini M.C., Palmieri V. et al. Central but not brachial blood pressure predicts cardiovascular events in an unselected geriatric population: the ICARe Dicomano Study. J. Am. Coll. Cardiol. 2008; 51: 2432-2439.

7. McEniery C.M., Yasmin, McDonnell B. et al. Central pressure: variability and impact of cardiovascular risk factors: the Anglo-Cardiff Collaborative Trial II. Hypertension 2008; 51: 1476-1482.

8. Jankowski P., Bilo G., Kawecka-Jaszcz K. The pulsatile component of blood pressure: its role in the pathogenesis of atherosclerosis. Blood Press. 2007; 16: 238-245.

9. Asmar R.G., London G.M., O'Rourke M.F., Safar M.E. Improvement in blood pressure, arterial stiffness and wave reflections with a very-low-dose perindopril/indapamide combination in hypertensive patients: a comparison with atenolol. Hypertension 2001; 38: 922-926.

10. Williams B., Lacy P.S., Thom S.M. et al. Differential impact of blood pressure-lowering drugs on central aortic pressure and clinical outcomes: principal results of the conduit artery function evaluation (CAFE) study. Circulation 2006; 113: 1213-1225.

11. Hirata K., Vlachopoulos C., Adji A., O’Rourke M.F. Benefits from angiotensin-converting enzyme inhibitor 'beyond blood pressure lowering: beyond blood pressure or beyond the brachial artery? J. Hypertens. 2005; 23: 551-556.

12. Morgan T., Lauri J., Bertram D., Anderson A. Effect of different antihypertensive drug classes on central aortic pressure. Am. J. Hypertens. 2004; 17: 118-123.

13. Dhakam Z., Yasmin, McEniery C.M. et al. A comparison of atenolol and nebivolol in isolated systolic hypertension. J. Hypertens. 2008; 26: $351-356$.

14. Wysocka M. Ciśnienie centralne w aorcie. On-line, pulsmedycyny.pl: http://pulsmedycyny.pl/2581377,40027, cisnienie-centralne-w-aorcie. 